\title{
Ultrastructural examination of bronchial biopsy specimens from children with moderate asthma
}

\author{
H Çokuğraş, N Akçakaya, İ Seçkin, Y Camcıŏ̆lu, N Sarımurat, F Aksoy
}

\begin{abstract}
Background-Few studies have evaluated the asthmatic airway in childhood. The aim of this study was to assess the histopathological changes occurring in the bronchi of children with moderate asthma using light and electron microscopy.

Methods-Bronchial biopsy specimens from 10 children with moderate asthma (seven boys) of mean (SD) age 9.3 (3.8) years (range 5-14) were examined by light and electron microscopy. Patients had not had a respiratory infection for at least one month and they had not been treated with steroids or sodium cromoglycate for four weeks before the study. Bronchoscopy was performed under general anaesthesia using a Karl Storz rigid paediatric bronchoscope. Biopsy materials were stained with uracyl acetate and lead citrate and evaluated under a Zeiss-10 electron microscope and light microscope.

Results-The most important finding was thickening and hyalinisation of the basement membrane in nine patients. The ciliated epithelial cells showed loss of cilia in some cases. Overactive fibroblasts were consistently found. Six patients had degranulating mast cells and lymphocyte infiltration in the submucosa. Eosinophils were seen in only one biopsy sample.

Conclusion-Children with moderate asthma develop bronchial inflammation similar to the reaction observed in adults. However, in our study the inflammation was rich in lymphocytes rather than eosinophils.

(Thorax 2001;56:25-29)
\end{abstract}

Keywords: paediatric asthma; lymphocytes; bronchoscopy; electron microscopy

Sükran Ciftligi Sok, Onur Ap. No. 35/15, Bakirköy, Istanbul, Turkey

H Çokuğraș

N Akçakaya

İ Seçkin

Y Camcioğlu

N Sarımurat

F Aksoy

Correspondence to: Dr H Çokuğraş hcokugras@turkpediatri.org.tr

Received 15 February 2000 Returned to authors 20 June 2000

Revised version received

8 August 2000

Accepted for publication

20 September 2000

Asthma is one of the most frequent chronic diseases of the respiratory tract in childhood. ${ }^{12}$ Airway inflammation is considered to be a crucial component for the chronicity of asthma and it is often associated with tissue remodelling. Descriptions of the pathological features of asthma have been largely based on necropsy studies of patients with status asthmaticus and, in recent years, on examination of bronchoalveolar lavage fluid and open or bronchoscopic biopsy specimens from asthmatic patients. ${ }^{3-5}$ Mucus plugging of the segmental bronchi and bronchioles, epithelial cell loss, goblet cell hyperplasia, thickening of the epithelial basement membrane, oedema of the submucosa, smooth muscle hypertrophy, and inflammatory cell infiltration are the characteristic pathological changes of the disease. However, there have been few studies of the pathological features of the airways in asthmatic children.

The aim of this study was to examine by light (LM) and electron microscopy (EM) bronchial biopsy specimens obtained from children with moderate asthma.

\section{Methods}

PATIENTS

Bronchial biopsy specimens from 10 asthmatic children were examined by light and electron microscopy. The patients comprised three boys and seven girls with a mean (SD) age of 9.3 (3.8) years (range 5-14) with moderate asthma who had been followed for $2.8(0.8)$ years in Cerrahpaşa Medical Faculty, Department of Pediatrics, Istanbul. The mean duration of the disease was 4.8 (2.0) years. The mean forced expiratory volume in one second $\left(\mathrm{FEV}_{1}\right)$ was $58(12) \%$ predicted (range 44-65) in seven cases; the other three patients did not cooperate with spirometric testing. After inhalation of $200 \mu \mathrm{g}$ salbutamol the mean $\mathrm{FEV}_{1}$ values increased to 78 (16)\% predicted. Subjects were classified as having moderate asthma according to the 1998 asthma consensus criteria. ${ }^{1}$ All patients had extrinsic asthma based on their clinical history (100\%), familial history (70\%), high serum IgE levels (100\%), and positive skin prick tests to common allergens $(100 \%)$. Six of the children also had allergic rhinitis and one had atopic dermatitis. All of the patients had been treated with sodium cromoglycate for 2.0 (0.8) years and had received inhaled steroids and bronchodilators for 8 (2) months before bronchoscopy. The study was approved by the Pediatric Studies and Research Committee of Cerrahpaşa Medical Faculty, University of Istanbul.

The clinical characteristics of the patients are shown in table 1 . Subjects were excluded if they suffered from tuberculosis, cystic fibrosis, or $\alpha_{1}$-antitrypsin deficiency.

At the time of the examination, all asthmatic subjects were clinically stable and had not experienced any respiratory infections for at least one month. Inhaled steroids and sodium cromoglycate were discontinued four weeks before bronchoscopy. ${ }^{7-11}$ Before stopping steroid treatment the consent of the parents was obtained, and parents were informed about the probable complications of stopping steroid treatment. Each patient was followed very closely. We agreed to give bronchodilators such as salbutamol in cases of exacerbation of asthma but during the four weeks prior to bronchoscopy no exacerbations occurred. 
Table 1 Clinical characteristics of the patients

\begin{tabular}{|c|c|c|c|c|c|c|c|c|c|c|}
\hline Case no & $\begin{array}{l}\text { Age } \\
\text { (years) }\end{array}$ & $\begin{array}{l}\text { Duration } \\
\text { of disease } \\
\text { (years) }\end{array}$ & $\begin{array}{l}\text { Monthly } \\
\text { wheezing }\end{array}$ & $\begin{array}{l}\text { Night } \\
\text { symptoms/ } \\
\text { month }\end{array}$ & $\begin{array}{l}\beta_{2} \text { use per } \\
\text { week }\end{array}$ & $\begin{array}{l}\text { Basal } \\
F E V_{1} \\
(\%)\end{array}$ & $\begin{array}{l}\text { Reversibility } \\
\text { of } F E V_{1}(\%)\end{array}$ & $\begin{array}{l}\text { Family } \\
\text { history of } \\
\text { atopy }\end{array}$ & $\begin{array}{l}\text { Total IgE } \\
\text { (IU/ml) }\end{array}$ & $\begin{array}{l}\text { Skin } \\
\text { tests }\end{array}$ \\
\hline 1 & 14 & 7 & 3 & 4 & $2-4$ & 59 & 20 & + & 960 & +++ \\
\hline 2 & 14 & 7 & 3 & 3 & $4-6$ & 61 & 16 & - & 920 & +++ \\
\hline 3 & 13 & 7 & 2 & 3 & $3-4$ & 60 & 15 & + & 1200 & +++ \\
\hline 4 & 6 & 4 & 4 & 4 & $5-6$ & 66 & 15 & + & 880 & +++ \\
\hline $5^{\star}$ & 13 & 7 & 5 & 7 & $7-8$ & 44 & 12 & + & 446 & ++ \\
\hline 6 & 5 & 2 & 2 & 5 & $4-6$ & - & $-\star \star \star \star$ & + & 902 & ++ \\
\hline 7 & 10 & 4 & 3 & 4 & $6-7$ & 58 & 18 & - & 1122 & +++ \\
\hline 8 & 5 & 3 & 4 & 3 & $3-4$ & - & $-\star \star \star \star$ & + & 800 & +++ \\
\hline 9 & 7 & 4 & 2 & 5 & $2-4$ & 65 & 19 & - & 440 & +++ \\
\hline 10 & 6 & 3 & 3 & 6 & $4-6$ & - & $-\star \star \star \star$ & + & 680 & ++ \\
\hline Median & $9.3(3.8)$ & 4.8 & 3.3 & 4.4 & $4.5-5.5$ & 58 & 16.7 & $7 / 10$ & $755(93)$ & $10 / 10$ \\
\hline
\end{tabular}

$\star$ Patient with eosinophilic infiltration.

$\star \star$ All patients were sensitive to mites.

${ }^{\star \star \star}$ Case nos 6,8 and 10 did not perform spirometric tests.

BRONCHOSCOPY

Each parent gave informed consent. Bronchoscopy was performed under general anaesthesia with atracurium besylate and halothane and patients were not premedicated. A Karl Storz rigid paediatric bronchoscope was inserted through the mouth. Two specimens were taken from the left main bronchus with a Karl Storz 10370-L circular cup biopsy forceps. ${ }^{12-14}$ All children tolerated the procedure well and no complications occurred in the postoperative period. There were no long term sequelae.

LIGHT MICROSCOPY

Biopsy specimens were dissected $4 \mu \mathrm{m}$ thick and stained with haematoxylin and eosin. Then they were examined under the light microscope.

ELECTRON MICROSCOPY

The biopsy material was fixed with glutaraldehyde and $4 \%$ phosphate solution mixture. The

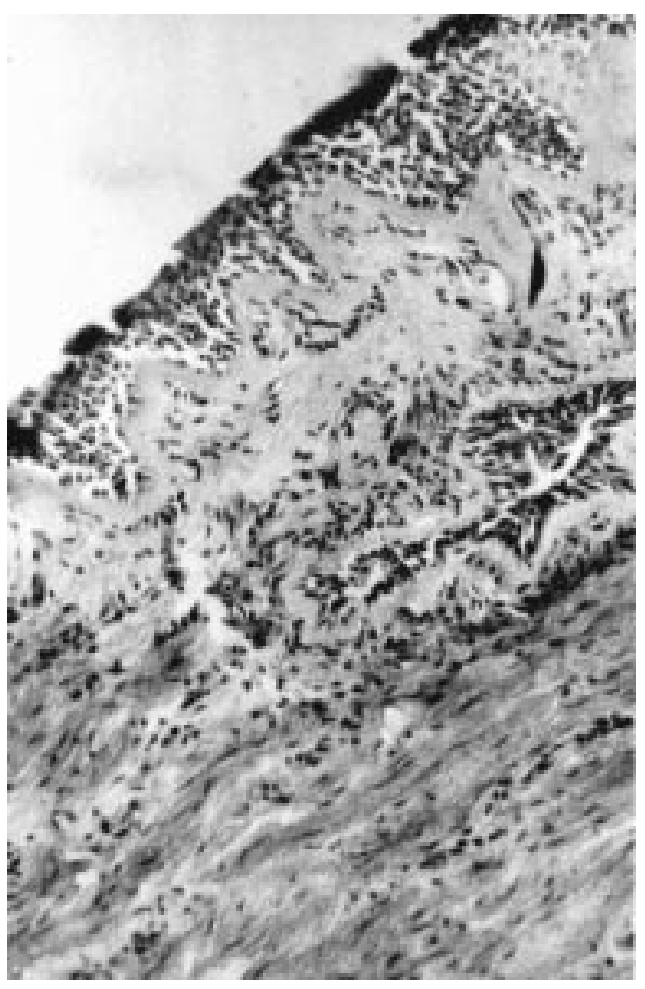

Figure 1 Thickness and hyalinisation of the basal membrane. The submucosa is infiltrated with lymphocytes (LM, ×400). same phosphate solution and osmium tetroxide were used for post fixation. Sections 600$700 \AA$ thick were obtained from the polymerised material with Reichert UM 2. The sections were stained with uracyl acetate and lead citrate and evaluated under a Zeiss M-10 electron microscope.

\section{Results}

LIGHT MICROSCOPY

The most important finding in nine patients was thickening and hyalinisation of the basement membrane (fig 1). Hyperplasia of the goblet cells was observed in only two cases. The submucosa was infiltrated with lymphocytes in six patients, and one also had eosinophilic infiltration.

ELECTRON MICROSCOPY

Three cases had electrolucent thick linear hyaline columns in the paraepithelial region. The active fibroblasts and increased collagen fibre deposition in the submucosa was quite striking (fig 2). The elongated fibroblasts, with enlarged granular endoplasmic reticulum cisternae, nuclei showing little invagination with sparse chromatin and peripherally condensed heterochromatin, were in close contact with the collagen fibres (fig 3). Moreover, in six cases

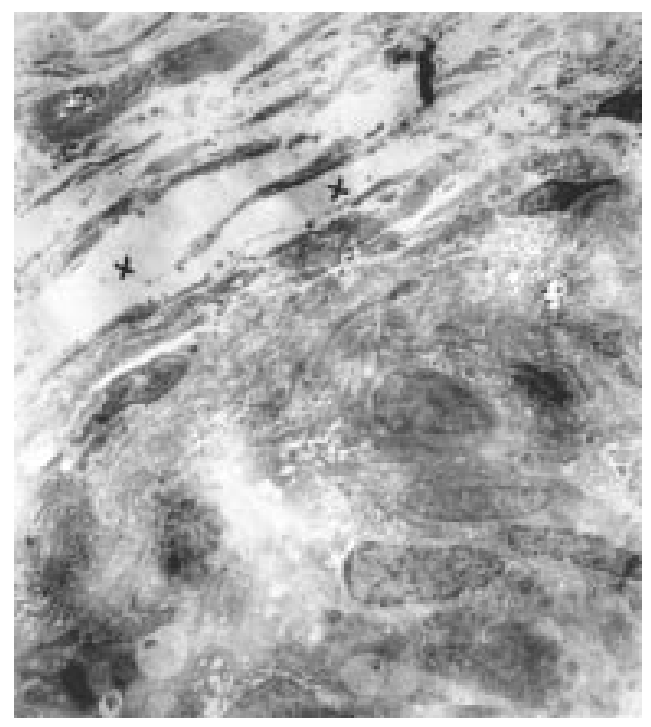

Figure 2 Electrolucent thick linear hyaline columns in the paraepithelial region $(x)$ and active fibroblasts (EM, $\times 5000)$. 


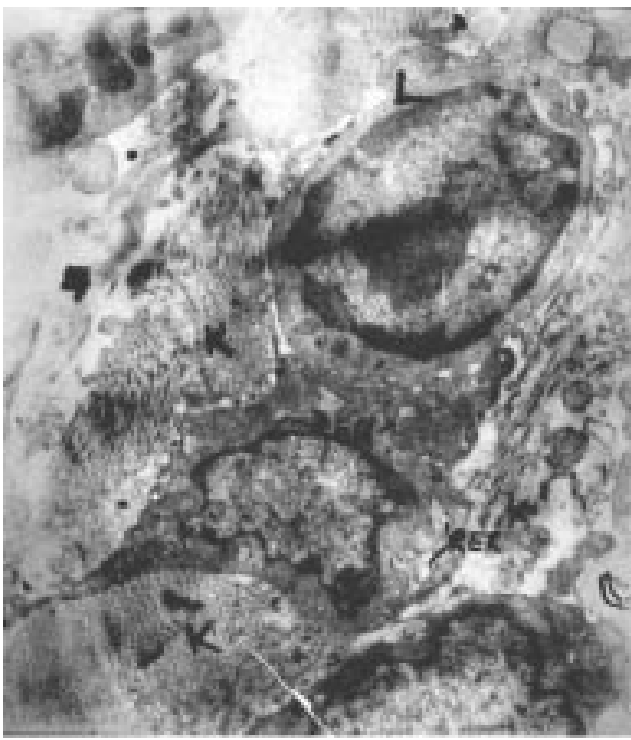

Figure 3 Fibroblasts with enlarged granular endoplasmic reticulum (RER), lymphocytes (L), and collagen fibres (K) $(E M, \times 20000)$.

atypical degranulating lymphocytes were demonstrated in the deep regions of the submucosa (figs 1, 3, 4). The compact nuclei of these cells were rich in heterochromatin with prominent invaginations. In some cases significant luminal narrowing was seen in the arterioles within the submucosa (fig 4). Another striking characteristic was the thrombi seen in the capillaries and arterioles in some patients (fig 5).

In the connective tissue a structure arranged in a linear pattern similar to fibrin was seen in some regions. In these regions, extravasation of red blood cells and eosinophils was also observed. In six cases degranulating mast cells were aggregated with partially emptied granules, especially near the arterioles (figs $4,5,6$ ). An increase in the glycogen content of the myoplasm of smooth muscle was also seen. The EM findings are summarised in table 2 .

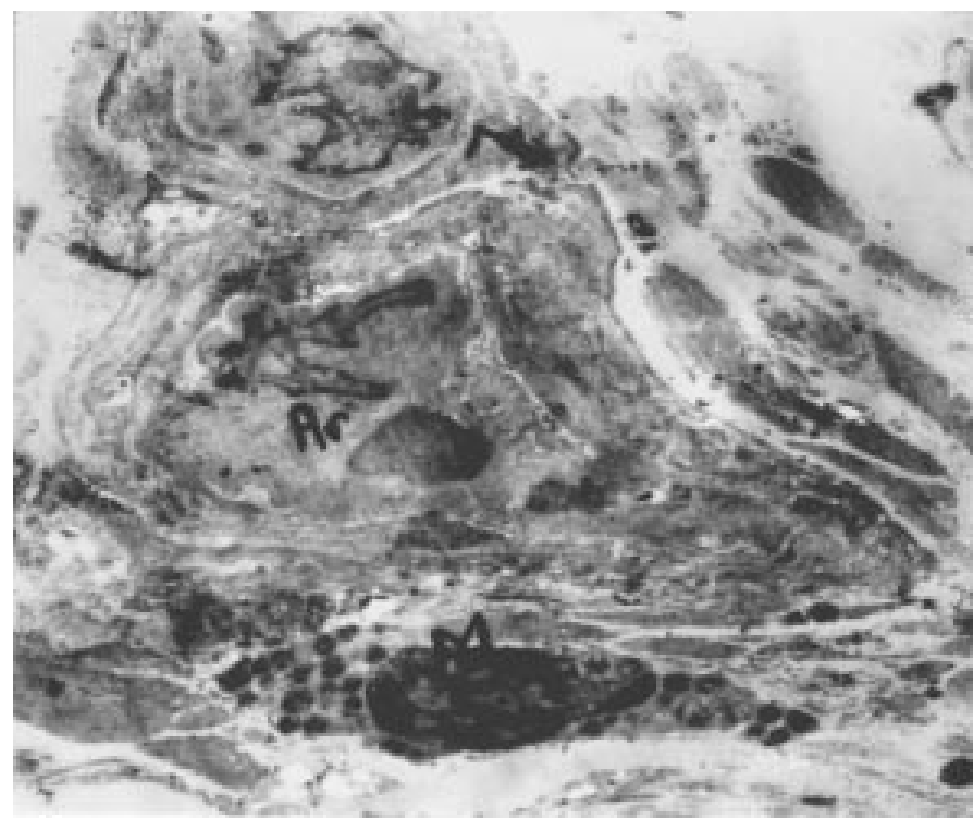

Figure 4 Lymphocytes (L), degranulating mast cells (M), and luminal narrowing in the arterioles $(A r)$ within the submucosa $(E M, \times 10$ 000)

\section{Discussion}

The aim of this study was to assess the histopathological changes occurring in the bronchi of children with moderate asthma. Most previous studies have been conducted in adults. Material obtained in necropsies and biopsies (open or bronchoscopic) of asthmatic patients have shown mucus plugs in the bronchi and bronchioles, loss of epithelium to varying degrees, goblet cell hyperplasia, thickening of the epithelial basement membrane, submucosal oedema and smooth muscle hypertrophy and, as a result, airway remodelling. ${ }^{15}$ Our patients were reasonably homogeneous with respect to laboratory findings, treatment, and response to treatment. Only one of the patients had lower $\mathrm{FEV}_{1}$ values than the others, but otherwise his clinical manifestations conformed to the criteria for moderate asthma in children.

The ciliated epithelial cells showed loss of their cilia in some cases. In recent years it has frequently been emphasised that the intact bronchial epithelium may have an important role in the pathogenesis of asthma since it not only constitutes a mechanical barrier, but also secretes bronchodilator substances. ${ }^{4591617}$ Failure of adequate adhesion of epithelial cells to the basement membrane may facilitate development of asthma by increasing antigen entry and consequent mediator response. ${ }^{3}{ }^{10}$ 18-20 The loss of epithelium observed might be considered artificial, although this possibility is less likely with the rigid bronchoscope used in this study. ${ }^{21}$ We believe that the epithelial changes were caused by the asthma itself and not by the rigid bronchoscope. ${ }^{22}$

Goblet cell hyperplasia responsible for the increased mucus secretion seen in asthma was found in only two of our cases.

Thickening and hyalinisation of the basement membrane to varying degrees in the subepithelial regions were characteristic features. However, there was no correlation between the duration of the disease and the extent of thickening of the basement membrane. On the other hand, different researchers have noted this change in patients with mild asthma. ${ }^{511} 23$ This finding is thought to be caused by an increase in collagen synthesis resulting from fibroblast activation rather than a functional disorder of the epithelium. ${ }^{24}{ }^{25}$ We consistently encountered overactive fibroblasts in our patients. There was an increased number of elongated cells; these cells had enlarged granular endoplasmic reticulum cisternae and their nuclei showed little invagination with sparse chromatin. These findings indicate that the fibroblasts were overactive. Besides causing thickening of the basement membrane by synthesising type III collagen, these fibroblasts may also be responsible for the hyalinisation seen in the lamina propria with the intercellular concentration of the amorphous material they secrete. It is claimed that most proteases may activate collagenesis and stimulate fibrogenesis in conjunction with eosinophils. Moreover, some mast cell mediators are thought to have trophic effects on fibroblasts. ${ }^{26}$ Thus, mast cells may be directly responsible for the thickening of the 


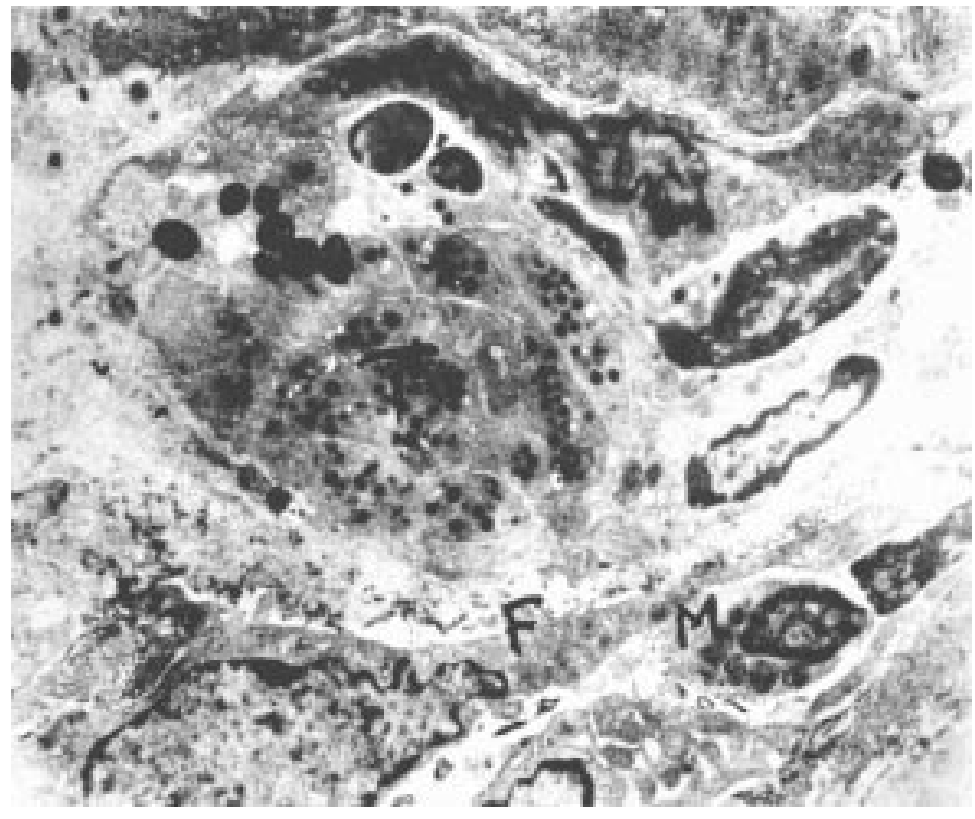

Figure 5 Thrombus in the arteriole $(T)$, fibroblast $(F)$, and mast cell (M) (EM, $\times 10$ 000).

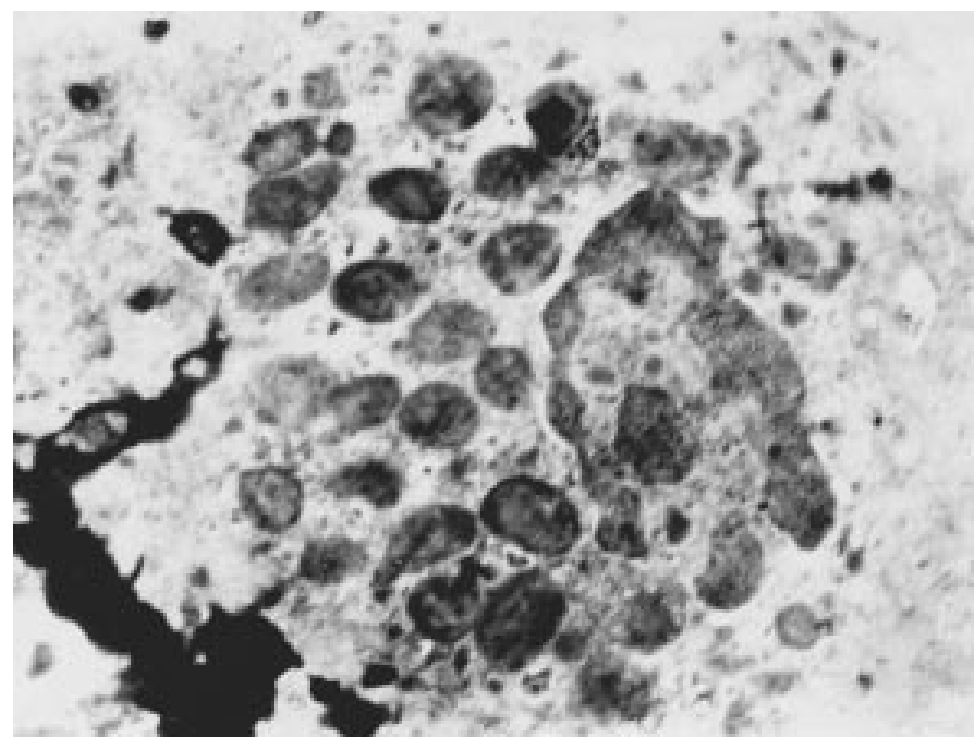

Figure 6 Degranulating mast cell $(E M, \times 20000)$.

basement membrane. Six of our cases had degranulating mast cells. These cells are known to be important effectors in allergic reactions through their release of preformed mediators and synthesis of new mediators in response to the interaction of surface $\operatorname{IgE}$ with antigen.
Eosinophils, which are claimed to be the hallmark in the differential diagnosis of asthma and other bronchial disorders ${ }^{27}$ were found in only one biopsy sample in our study. This finding was similar to studies reported by Laitinnen and Jeffery. ${ }^{41}$ The patient with eosinophilic infiltration in his biopsy specimens was indistinguishable clinically from the other patients except that his $\mathrm{FEV}_{1}$ value was lower than the others; however, the reversibility of $\mathrm{FEV}_{1}$ was as good as in the other patients. The duration of asthma in this patient was also no longer than in the others. Th2 type lymphocytes secreting mediators of allergic inflammation such as interleukin (IL)-4, IL-5, IL-10, and IL-13 and B lymphocytes producing IgE are central to the pathophysiology of asthma. ${ }^{28}$ In patients with severe asthma and in asthma related deaths a dense lymphocytic infiltration has been observed in the bronchial walls. However, in recent years it has been reported that mild asthma is also accompanied by extensive inflammatory changes in the airways. ${ }^{11}{ }^{29}$ Lymphocytes, which were observed in our study subjects, are therefore not related to the severity of asthma.

In acute fatal asthma clusters of platelets are seen in pulmonary vessels. ${ }^{30}$ Platelets can synthesise pro-inflammatory mediators and can participate in inflammatory reactions. They also possess low affinity IgE receptors. Although the role of platelets in airway inflammation is only speculative, the frequent appearance of platelet clusters in the arterioles of our patients supports this theory. Smooth muscle cells displaying increased invagination and glycogen stores have led to the conclusion that increased smooth muscle contraction occurs. These findings combine to indicate that asthma is a disease with airway remodelling which may lead to permanent tissue destruction in children, as in adults. Case-control studies might be helpful to confirm these results, but it is unethical to take bronchial biopsy specimens from non-asthmatic children.

In conclusion, children with moderate asthma develop bronchial inflammation similar to the reaction observed in adults. However, this inflammation is rich in lymphocytes rather than eosinophils. Basement thickening is a frequent finding and intra-arteriolar platelet clusters and increased smooth muscle contractility are also observed.

Table 2 Electron microscopic (EM) findings of asthmatic children

\begin{tabular}{|c|c|c|c|c|c|c|c|c|}
\hline Case no & $\begin{array}{l}\text { Loss of } \\
\text { ciliated cells }\end{array}$ & $\begin{array}{l}\text { Lymphocyte } \\
\text { infiltration }\end{array}$ & $\begin{array}{l}\text { Eosinophil } \\
\text { infiltration }\end{array}$ & $\begin{array}{l}B M \\
\text { thickening }\end{array}$ & $\begin{array}{l}\text { Degranulating } \\
\text { mast cells }\end{array}$ & $\begin{array}{l}\text { Active } \\
\text { fibroblast }\end{array}$ & $\begin{array}{l}\text { Goblet cell } \\
\text { hyperplasia }\end{array}$ & $\begin{array}{l}\text { Collagen } \\
\text { synthesis }\end{array}$ \\
\hline 1 & + & + & & & & + & & \\
\hline 2 & & + & & & + & + & & \\
\hline 3 & + & + & & & & + & & + \\
\hline 4 & + & & + & & + & + & + & \\
\hline $5^{\star}$ & & & & & + & + & & + \\
\hline 6 & & + & & & & & & \\
\hline 7 & + & 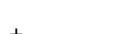 & & + & + & + & + & \\
\hline $\begin{array}{l}8 \\
9\end{array}$ & $\begin{array}{l}+ \\
+\end{array}$ & $\begin{array}{l}+ \\
+\end{array}$ & & + & + & & & \\
\hline 10 & & & & & + & + & & \\
\hline N (\%) & $6(60 \%)$ & $6(60 \%)$ & $1(10 \%)$ & $3(30 \%)$ & $6(60 \%)$ & $7(70 \%)$ & $2(20 \%)$ & $2(20 \%)$ \\
\hline
\end{tabular}

*This patient had the lowest $\mathrm{FEV}_{1}$ values. 
1 Warner JO, Naspitz CK, Cropp GJA. Third international pediatric consensus statement on the management of pediatric consensus statement on the managem
childhood asthma. Pediatr Pulmonol 1998;25:1-17.

2 Remes ST, Korppi M, Remes K, et al. Prevalence of asthma at school age: a clinical population-based study in eastern Finland. Acta Paediatr 1996;85:59-63.

3 Holgate ST. The 1992 Cournand lecture. Asthma: past, present, and future. Eur Respir $\mathcal{F}$ 1993;6:1507-20.

4 Laitinen A, Laitinen LA. Pathology of asthma. Allergy Proc 1994;15:323-8.

5 Laitinen A, Laitinen LA. Airway morphology: epithelium/ basement membrane. Am f Respir Crit Care Med 1994;150 14-7.

6 Dukes MNG, Holgate ST, Pauwels RA. Report of an international workshop on risk and safety of asthma therapy. Clin Exp Allergy 1994;24:160-5.

7 Glynn AA, Michaels L. Bronchial biopsy in chronic bronchitis and asthma. Thorax 1960;15:142-53.

8 Lacoste JY, Bousquet J, Chanez P, et al. Eosinophilic and neutrophilic inflammation in asthma, chronic bronchitis, neutrophilic inflammation in asthma, chronic bronchitis,
and chronic obstructive pulmonary disease. F Allergy Clin and chronic obstructive pulm

9 Laitinen LA, Heino M, Laitinen A, et al. Damage of the airway epithelium and bronchial reactivity in patients with asthma. Am Rev Respir Dis 1985;131:599-606.

10 Beasley R, Burgess C, Crane J, et al. Pathology of asthma and its clinical implications. F Allergy Clin Immuno 1993;92:148-54.

11 Jeffery PK, Wardlaw AJ, Fiona C, et al. Bronchial biopsies in asthma. Am Rev Respir Dis 1989;140:1745-53.

12 Raine J, Warner JO. Fiberoptic bronchoscopy without general anesthetic. Arch Dis Child 1991;66:481-4

13 Perez CR, Wood RE. Update on pediatric flexible bronchoscopy. Pediatr Clin N Am 1994;41:385-99.

14 Humbert M, Robinson DS, Assoufi B, et al. Safety of fibreoptic bronchoscopy in asthmatic and control subjects and effect on asthma control over two weeks. Thorax 1996;51: 664-9.

15 Elias JA, Zhou Z, Chupp G, et al. Airway remodelling in asthma. F Clin Invest 1999;104:1001-6.

16 Raeburn D, Webber SE. Proinflammatory potential of the airway epithelium in bronchial asthma. Eur Respir $\mathcal{f}$ 1994;7:2236-30.
17 Rennard SI, Romberger DJ, Sisson JH, et al. Airway epithelial cells: functional roles in airway disease. Am ₹ Respir Crit Care Med 1994;150:527-30.

18 Vanhoutte PM. Epithelium derived relaxing factors and bronchial reactivity. Am Rev Respir Dis 1988;183:524-30.

19 Södeberg M, Hellström S, Sandström T, et al. Structural characterization of bronchial biopsies from healthy volunteers: a light and electron microscopical study. Eur Respir 7 1990;3:261-6.

20 Gizycki MJ, Adelroth E, Rogers V, et al. Myofibroblast involvement in the allergen induced late response in mild
atopic asthma. Am $\mathcal{F}$ Respir Cell Mol Biol 1997;16:664-73.

21 Laitinen LA, Laitinen A, Haahtela A. Airway mucosal inflammation even in patient with newly diagnosed asthma. Am Rev Respir Dis. 1993;147:697-704

22 Laitinen LA, Heino M, Laitinen A, et al. Damage of the airway epithelium and bronchial reactivity in patients with asthma. Am Rev Respir Dis 1985;131:599-606.

23 Chu HW, Halliday JL, Martin RJ, et al. Collagen deposition in large airways may not differetiate severe asthma from milder forms of the disease. Am $\mathcal{f}$ Respir Crit Care Med 1998;158:1936-44.

24 Schlosberg M, Liu MC, Bochner BS. Pathophysiology of asthma. Immunol Allergy Clin North Am 1993;13:727.

25 Roche WR, Beasley R, Williams JH, et al. Subepithelial fibrosis in the bronchi of asthmatics. Lancet 1989;139:5203.

26 Vignola AM, Chanez P, Campbell AM, et al. Airway inflammation in mild intermittent and in persistent asthma. Am $\mathcal{f}$ Respir Crit Care Med 1998;157:403-9.

27 Busse WW, Calhoun WF, Sedgwick JD. Mechanism of airway inflammation in asthma. Am Rev Respir Dis 1993;147:20-4.

28 Anuradha R, Cohn L. Th2 cells and GATA-3 in asthma: new insights into the regulation of airway inflammation. $f$ Clin Invest 1999;104:985-93.

$29 \mathrm{McFadden}$ ER. Asthma: morphologic-physiologic interactions. Am f Respir Crit Care Med 1994;150:23-6.

30 Schneider RC, Zapol WM, Carvatho AC. Platelet consumption and sequestratrion in severe acute respiratory failure. Am Rev Respir Dis 1980;122:445-9. 